Wiesław WACŁAWCZYK

Uniwersytet Mikołaja Kopernika, Toruń

\title{
Koncepcja ,wolnego rynku idei” i perspektywy jej dalszego rozwoju
}

Dojęcie „wolnego rynku idei” wywiera dziś niewątpliwie zasadniczy wpływ na kształtowanie się współczesnych standardów swobody wypowiedzi. Jego znaczenie trudno wprost przecenić, jeśli weźmie się pod uwagę słowa Freda S. Sieberta, podkreślającego, że dwa wiążące się ze sobą pojęcia: free marketplace of ideas (wolny rynek idei) oraz self-righting process (proces samoregulujący się) konstytuują liberalną teorię prasy, pozostającą „od ponad dwustu lat przewodnią zasadą zachodniej cywilizacji"'.

Oba wymienione tu terminy wiążą się nierozerwalnie z nazwiskiem Johna Miltona, który w swym traktacie Areopagitica - napisanym w 1644 roku w formie klasycznej oracji, adresowanej do parlamentu angielskiego - zawarł sformułowania uznawane dziś za fundament koncepcji „,wolnego rynku idei”. Zaangażowany po stronie republikanów w wewnętrznym konflikcie targającym Anglią w latach 1640-1660, Milton wystąpił w Areopagitica z ostrym atakiem przeciwko cenzurze, wyrażając przekonanie, że jeśli zagwarantuje się w kraju wolność słowa, idee prawdziwe potrafią wyjść zwycięsko z konfrontacji z fałszem i zakłamaniem. Przekonanie to znalazło szczególnie silny wyraz w następującym fragmencie tekstu:

„I choćby wiatry wszystkich doktryn rozszalały się po świecie i Prawda znalazła się w opałach, to wątpiąc w jej siłę - cenzurując i zakazując wyrządzamy jej krzywdę. Niech Prawda i Fałsz walczą ze sobą - kto kiedy widział, by Prawda w równym i otwartym starciu została pokonana?... Któż nie wie, że Prawda ustępuje siłą tylko Wszechmogącemu? Nie potrzebuje ustaw, podstępów, cenzury, żeby odnieść zwycięstwo - to są kruczki, którymi walczy z nią fałsz. Dajcie jej tylko dość przestrzeni i nie

1 F. S. Siebert, Libertarian Theory of the Press, w: F. S. Siebert, Theodore Peterson $i$ Wilbur Schramm, Four Theories of the Press, University of Illinois, Urbana 1956, s. 70. 
krępujcie jej podczas snu, bo wtedy nie powie prawdy, tak jak stary Proteusz, który mówił zagadkami tylko wtedy, gdy go schwytano i skrępowano; wtedy przyjmie raczej dowolny kształt - poza swoim własnym i może dostroi swój głos do oczekiwań epoki - jak Micheasz przed Achabem - aż pozwolą jej powrócić do pierwotnej postaci"².

To właśnie z tym krótkim fragmentem Miltonowskiej mowy do parlamentu angielskiego w obronie wolności druku kojarzy się dziś głównie dwa przywołane wyżej pojęcia: free marketplace of ideas i self-righting process. Pierwsze z nich jest postulatem dopuszczenia do swobodnej konfrontacji różnych poglądów, drugie wyraża wspomniane przekonanie, że w takich warunkach prawda jest zdolna wykazać swą wyższość nad fałszem.

Wyraz ,przekonanie” ma tu swoje uzasadnienie. Jak zaznacza John C. Merrill, komentując stanowisko autora Areopagitica w tej kwestii, Milton nawet nie starał się udowodnić, że self-righting process znajduje uzasadnienie w rzeczywistości. Zamiast tego ograniczył się do wypowiedzenia zacytowanej wyżej myśli ${ }^{3}$. Z tego powodu wielu filozofów - dodaje Merrill - takich, jak John Stuart Mill, zignorowało ją, uznając self-righting process wyłącznie za „mit retoryczny".

Akurat w odniesieniu do J. S. Milla opinia ta nie wydaje się do końca prawdziwa, ten bowiem nie kwestionował całkowicie samej zdolności prawdy do odnoszenia triumfu nad fałszem, zwracał natomiast uwagę na to, jak trudny i żmudny może się to okazać proces. Pogląd Milla dotyczący omawianego tu zagadnienia oddaje najlepiej następujący fragment jego opublikowanego w 1859 roku eseju $O$ wolności:

„Twierdzenie, że prawda, po prostu jako prawda posiada jaką́s wrodzoną siłę przezwyciężania więzień i stosów, której pozbawione są błędy, jest wytworem bezpodstawnego sentymentalizmu. Ludzie nie służą gorliwiej prawdzie niż omyłce, a dostateczne zastosowanie prawnych lub nawet społecznych kar kładzie zwykle kres propagandzie tak jednej, jak drugiej. Rzeczywista przewaga prawdy polega na tym, że gdy opinia jest prawdziwa, można ją zagłuszyć raz, dwa razy lub wielokrotnie, lecz w ciagu wie-

2 J. Milton, Areopagitica: Mowa do parlamentu angielskiego w obronie swobody druku, A. Pawelec: thumaczenie wybranych fragmentów, czasopismo „Znak” 1993, nr 6, s. 53.

3 J. C. Merrill, J. Milton, w: Legacy of Wisdom. Great Thinkers and Journalism, Iowa State University Press, Ames 1994, s. 44.

4 Ibidem. 
ków znajdą się zazwyczaj ludzie, którzy ją będą odkrywać na nowo, póki nie pojawi się w momencie, gdy sprzyjające okoliczności pozwolą jej uniknąć prześladowania i wzmóc się na tyle, by odeprzeć wszystkie późniejsze próby jej zdławienia" 5 .

Esej $O$ wolności został opublikowany w 215 lat po ukazaniu się Areopagitica. Niezależnie od różnic dzielących autorów obu tych dzieł w kwestiach dotyczących wolności słowa, należy podkreślić, że czynnikiem łączącym ich poglądy na ten temat było przekonanie, że to właśnie swobodna wymiana idei jest mechanizmem pozwalającym na poszukiwanie prawdy w życiu publicznym. Również opinie fałszywe mają na tym rynku rację bytu, co J. S. Mill uzasadniał w następujący sposób: „Gdyby cała ludzkość z wyjątkiem jednego człowieka sądziła to samo i tylko ten jeden człowiek był odmiennego zdania, ludzkość byłaby równie mało uprawniona do nakazania mu milczenia, co on, gdyby miał po temu władzę, do zamknięcia ust ludzkości. Gdyby opinia była osobistym mieniem mającym wartość jedynie dla właściciela, gdyby zakaz jej wyznawania był tylko jej krzywdą prywatną, istniałaby pewna różnica między wyrządzeniem tej krzywdy tylko kilku lub też wielu osobom. Ale szczególnie złą stroną zmuszania opinii do milczenia jest to, że ograbia ono cały rodzaj ludzki; zarówno przyszłe pokolenia jak współczesnych, a tych, którzy się nie godzą z daną opinią, bardziej jeszcze niż tych, którzy ją głoszą. Jeśli ta opinia jest słuszna, pozbawia się ich sposobności dojścia do prawdy; jeśli niesłuszna, tracą coś, co jest niemal równie wielkim dobrodziejstwem: jaśniejsze zrozumienie i żywszą świadomość prawdy wywołane przez jej kolizję z błędem"6.

Obaj - John Milton i J. S. Mill uważali wolność słowa za naturalne prawo jednostki, podkreślając przy tym, że jego uznanie jest niezbędnym warunkiem odkrywania prawdy w życiu publicznym. Aby zwrócić uwagę na podobieństwo ich poglądów w tej kwestii, warto przywołać jeszcze inne fragmenty obu cytowanych wyżej tekstów, zaczynając od urywku $O$ wol$n o s ́ c i$, w którym Mill streszcza swoje argumenty w obronie swobody słowa. Oto ten fragment:

„Po pierwsze, jeśli zmuszamy jakąś opinię do milczenia, nie możemy być pewni, że nie jest ona prawdziwa. Zaprzeczać temu oznacza zakładać własną nieomylność.

5 J. S. Mill, O wolności (przekład A. Kurlandzka), Wydawnictwo AKME, Warszawa 1999, s. 44-45.

6 J. S. Mill, op. cit., s. 32. 
Po drugie, choćby opinia, której kazano zamilknąć, była błędem, może ona zawierać i zwykle zawiera cząstkę prawdy. Ponieważ ogólna lub panująca opinia w jakimkolwiek przedmiocie rzadko lub nigdy nie jest całą prawdą, reszta prawdy może do nas dotrzeć tylko dzięki kolizji między przeciwnymi opiniami.

Po trzecie, nawet jeśli przyjęta opinia jest całkowicie prawdziwa, lecz nie może ścierpieć, by ktoś ją mocno i poważnie zwalczał, będzie wyznawana przez większość tych, którzy ją przyjmuja, podobnie jak przesąd, bez głębokiego zrozumienia lub odczucia jej uzasadnienia. I nie koniec na tym, lecz po czwarte, znaczenie samej doktryny zaginie lub osłabnie i utraci swój żywotny wpływ na postępowanie i charakter; dogmat stanie się czczą formalnością i zamiast skłaniać do dobrego, będzie tylko zajmować miejsce, nie dopuszczając do rozwijania się rzeczywistych i gorących przekonań wyrosłych z rozumu lub osobistego doświadczenia"7 .

Należy podkreślić, że pogląd wyrażony w cytowanym fragmencie przypomina opinię Miltona na temat prawdy jako pojęcia nabierającego znaczenia w konfrontacji z fałszem. Autor Areopagitica, porównując za Biblią prawdę do „tryskającej fontanny”, zaznacza, że „nasza wiara i wiedza rozwijają się w ćwiczeniu", podobnie jak członki ciała ${ }^{8}$. Gdy tego ćwiczenia brakuje, wiedza i wiara stają się „błotnistym stawem konformizmu i tradycji”. Milton rozwija ten wątek, dodając: „Człowiek może być heretykiem w prawdzie. Jeżeli wierzy w coś tylko dlatego, że jego pastor tak mówi albo Zgromadzenie tak orzeka [Zgromadzenie Westminster przyp. aut.], nie znając po temu innych powodów, to prawda, którą wyznaje, staje się jego herezją, mimo że jego wiara jest prawdziwa"10.

W świetle cytowanych wyżej fragmentów traktatu Miltona wydaje się oczywiste, że argumenty autora pierwszego w historii zwartego dzieła w obronie swobody wypowiedzi wynikają w dużym stopniu z jego prze-

7 Ibidem, s. 68-69.

8 Areopagitica. A Speech of Mr. John Milton for the Liberty of Unlicenced Printing, to the Parlament of England, http://www.dartmouth.edu/'milton/reading_room/areopagitica/part_2/text.html, part 2, s. 4; odczyt: 20.02.2004. We wspomnianym porównaniu Miltona prawdy do „tryskającej fontanny” autorzy „Uwag” do cytowanego tu wydania traktatu dopatrują się odwołań m.in. do Księgi Przysłów (18:4) - patrz: Areopagitica - part 2, Notes, http://www.dartmouth.edu/'milton/reading_room/areopagitica/part_2/notes.html, part 2, s. 4.

9 Areopagitica, op. cit., s. 4.

10 Ibidem, s. 4-5. 
konań religijnych. Zwracając na to uwagę, warto jednak dodać, iż twórca Raju utraconego odwoływał się w Areopagitica nadzwyczaj często do opinii myślicieli starożytnej Grecji i Rzymu. Sam tytuł jego oracji do parlamentu angielskiego jest wyraźnym nawiązaniem do mowy ateńskiego retora Izokratesa Logos Areopagiticos, wzywającej do przywrócenia w greckim państwie-mieście instytucji Areopagu, czyli zgromadzenia politycznego i sądowniczego obradującego na wzgórzu o tej nazwie. Krótko mówiąc, Milton, przedstawiając w swym pionierskim dziele propozycję „wolnego rynku idei”, dawał wyraźnie do zrozumienia, że zależy mu na tym, aby prawo bytu na tym rynku miały poglądy reprezentujące różne punkty widzenia, zarówno w kwestiach religijnych, jak i świeckich.

Poglądy Johna Miltona i Johna Stuarta Milla na temat swobody wypowiedzi znajdą później odzwierciedlenie w koncepcji sędziego Sądu Najwyższego USA, Olivera Wendella Holmesa. Przedstawił ją on w związku ze sprawą Abrams przeciwko Stanom Zjednoczonym, rozpatrywaną przez ten sąd w roku 1919. Holmes powiedział wówczas między innymi:

„Ściganie za wyrażanie poglądów może się wydawać w pełni logiczne. Ten, kto nie ma żadnych wątpliwości co do własnej słuszności i siły, a z całego serca pragnie osiagnąć jakiś rezultat, swe dążenia przeobraża w szatę prawną i likwiduje wszelki opór. Gdy jednak ludzie zdali sobie sprawę, że bieg wydarzeń pokonał już niejedną wojującą wiarę, mogą dojść do przekonania silniejszego nawet niż to, które dotyczy samych podstaw ich postępowania, a mianowicie, że najwartościowsze dobro jest łatwiej osiągnąc drogą wolnej wymiany idei, że najlepszym kryterium prawdy jest zdolność uzyskania przez daną ideę akceptacji w warunkach wolnorynkowej konkurencji oraz że prawda jest jedyną podstawą, na której możemy realizować bezpiecznie nasze zamierzenia"11.

Warto zaznaczyć, że to właśnie dzięki Oliverowi W. Holmeswi zaczęto już oficjalnie używać pojęcia „wolny rynek idei”. Zgodnie ze stanowiskiem amerykańskiego sędziego, przedstawionym w związku ze sprawą Abrams przeciw Stanom Zjednoczonym, ,najlepszym środkiem zaradczym wobec szkodliwych wypowiedzi jest przeciwstawienie im innych, aż wreszcie zwycięży pogląd najwłaściwszy"12.

11 S. Frankowski, R. Goldman, E. Łętowska, Sqad Najwyższy USA. Prawa i wolności obywatelskie, OSCE, Warszawa 1998, s. 112.

12 Ibidem, s. 113. 
Nie ulega wątpliwości, że formułując swą koncepcję, Holmes odwoływał się do myśli Miltona i J. S. Milla. Pisze o tym między innymi Max Lerner w swej książce poświęconej mowom, piśmiennictwu i opiniom prawnym sędziego Sądu Najwyższego USA ${ }^{13}$. Podkreślając idealistyczny charakter jego koncepcji, wyrażający się przekonaniem, że „to, co prawdziwe, przetrwa" (a nie pragmatyczny, mający za kryterium zasadę, że właśnie to, co ma zdolność przetrwania, jest prawdziwe), autor ten pisze dalej: „Pod tym względem Holmes jest bezpośrednim kontynuatorem tradycji Miltonowskiej Areopagitica i O wolności Milla" ". . Również Charles Levendosky zaznacza, iż wyrażając swoje zdanie odrębne w przywołanej tu sprawie, amerykański sędzia „zapożyczył się" u obu angielskich myślicieli ${ }^{15}$.

W latach dwudziestych minionego stulecia rzecznikiem „wolnego rynku idei” w Stanach Zjednoczonych pozostawał także inny sędzia Sądu Najwyższego - Louis Brandeis. W swej opinii wyrażonej w sprawie Whitney przeciwko Kaliforni kładł on nacisk na znaczenie wolności wypowiedzi w życiu społeczeństwa demokratycznego, zwracając uwagę na to, jakie cele przyświecały autorom Pierwszej Poprawki do Konstytucji USA, głoszącej między innymi, że „Kongres nie może uchwalać ustaw ograniczających wolność wypowiedzi"16. Brandeis tak pisał o wspomnianych celach twórców Pierwszej Poprawki:

„Wiedzieli oni, że porządku nie może zagwarantować sam tylko strach przed karą za tego porządku naruszenie; że niebezpieczne jest odwodzenie ludzi od myślenia, nadziei i wyobraźni; że strach rodzi represję; że represja rodzi nienawiść; że nienawiść zagraża stabilności rządów; że bezpieczna droga to droga swobodnej dyskusji nad domniemanymi żalami i proponowanymi środkami zaradczymi; i wreszcie że właściwą ochroną przed złymi doradcami są dobrzy doradcy. Wierząc w siłę rozumu, jaki przejawia się w publicznej debacie, twórcy Poprawki zrezygnowali z wymuszonego prawem milczenia - argumentu siłowego w najgorszej postaci. Zdając sobie sprawę z występującej niekiedy tyranii ze strony rządzącej

13 Patrz: M. Lerner (ed.), The Mind and Faith of Justice Holmes. His Speeches, Essays, Letters and Judicial Opinions, Little, Brown and Company, Boston 1946.

14 Ibidem, s. 290.

15 Ch. Levendosky, Marketplace Keeps Speech Free of Government Controls, „Casper Star-Tribune”, 17 July, 1997; wersja elektroniczna artykułu w: First Amendment Cyber-Tribune „Fact”, http://w3.trib.com/FACT/1st.lev.internet.marketplace.html, s. 1, odczyt: 24.01.2002.

16 S. Frankowski..., op. cit., s. 109. 
większości, znowelizowali Konstytucję w ten sposób, by gwarantowała ona wolność słowa i zgromadzeń"17.

Wydaje się celowe dodać, że wspólnym mianownikiem poglądów Miltona, Milla, Holmesa i Brandeisa - była niechęć do przesądów i wszelkich form dogmatyzmu. W przypadku pierwszego z nich niechęć ta okazała się tak silna, że w Areopagitica odmówił on prawa do wolności od cenzury prewencyjnej - Kościołowi katolickiemu, właśnie dlatego, że instytucję tę uważał za uosobienie obskurantyzmu ${ }^{18}$.

Również sędzia Holmes nie proponował wolności słowa bez ograniczeń. Sformułował on w związku z tym regułę pozwalającą na ingerencję władz w prawo mieszkańców kraju do korzystania z wolności słowa w sytuacji „wyraźnego i aktualnego niebezpieczeństwa” (clear and present danger) szkodliwych skutków, jakie mogą z sobą nieść niektóre wypowie$\mathrm{dzi}^{19}$. Aby jasno zilustrować swój pogląd w tej sprawie, Holmes odwołał się do znanego zwrotu, wielokrotnie później powtarzanego przy okazji rozpatrywania różnych spraw dotyczących wolności słowa: „Nawet najbardziej rygorystyczna ochrona swobody wypowiedzi nie objęłaby człowieka, który w teatrze pełnym ludzi świadomie wywoła fałszywy alarm okrzykiem 'pali się!' i spowoduje w ten sposób panikę"20.

Koncepcja „wolnego rynku idei”, sformułowana przez Johna Miltona i Johna Stuarta Milla, a wprowadzona do orzecznictwa sądowego przez sędziów Sądu Najwyższego USA: Olivera W. Holmesa i Louisa Brandeisa, wywarła zasadniczy wpływ na formowanie się współczesnych standardów wolności słowa. Najwcześniej znalazło to odzwierciedlenie w Stanach Zjednoczonych. Tutaj wspomniany sąd ,zaakceptował ostatecznie stanowisko Holmesa i Brandeisa w 1969 roku w sprawie Brandenburg przeciw Ohio"21.

Jednak już pięć lat wcześniej, w słynnej sprawie „New York Times” przeciw Sulivanovi, sędzia SN William Brennan przedstawił tam opinię, którą można uznać za dowód urzeczywistnienia Miltonowskiej propozy-

17 Ibidem, s. 113-114.

18 W końcowej części traktatu Milton pisał: „Nie mówię tu o tolerowaniu papiestwa ani otwartych przesądów, bo skoro podważają one wszystkie religie oraz władzę państwową, same powinny być zniszczone - oczywiście po użyciu wszystkich miłosiernych środków, żeby zdobyć i odzyskać słabych i zwiedzionych" (patrz: J. Milton, op. cit., s. 54).

19 S. Frankowski..., op. cit., s. 110.

20 Ibidem.

21 Ibidem, s. 115. 
cji free marketplace of ideas w praktyce prawnej nowoczesnego państwa demokratycznego. Brennan powiedział wówczas: „Rozpatrujemy tę sprawę na tle całkowitej w naszym kraju aprobaty dla zasady, wedle której debata na tematy publiczne powinna być swobodna, żywa i otwarta, przy czym dopuszcza się gwałtowne, uszczypliwe, a niekiedy wręcz nieprzyjemne i ostre ataki na władzę i funkcjonariuszy publicznych"22.

Jak zwraca uwagę Wojciech Sadurski, zasada sformułowana w Stanach Zjednoczonach „w przełomowej decyzji «New York Times» v. Sullivan z 1964 roku" stała się w jakimś stopniu wzorem dla sędziów Europejskiego Trybunału Praw Człowieka w Strasburgu ${ }^{23}$. Sadurski podkreśla, że dotyczyło to takich spraw jak Lingens przeciw Austrii z 1986 r. czy też Oberschlick przeciw Austrii z 1991 roku $^{24}$. Listę tę można by z pewnością znacznie wydłużyć - choćby o takie rozstrzygnięcia, jak te które zapadły w sprawach Castells przeciw Hiszpanii z 1992 r. lub Oberschlick (2) przeciw Austrii z 1997 r.

W sprawach, w których chodzi o zachowanie dobrego imienia osób publicznych, zwłaszcza zaś polityków i innych przedstawicieli władzy, ETPC zajmuje dość konsekwentnie stanowisko wyrażone przy okazji wspomnianego wyżej rozstrzygnięcia Lingens przeciw Austrii. Wówczas Trybunał stwierdził: „Politycy świadomie i w sposób nieunikniony wystawiają się na kontrolę i ostrą reakcję na każde wypowiedziane słowo i wszystko, co robią dziś i czynili w przeszłości. Muszą więc być bardziej tolerancyjni, nawet wobec szczególnie brutalnych ataków przeciwko nim"25.

Powtarzając ten sposób rozumowania w związku ze sprawą Oberschlick (2) przeciw Austrii - w której przedmiotem skargi był artykuł zawierający epitet ,idiota”, użyty wobec lidera Austriackiej Partii Wolności J. Haidera - Trybunał dodał: „W demokratycznym społeczeństwie należy przede wszystkim zagwarantować, by dyskusja polityczna mogła się szeroko oraz otwarcie toczyć. Wszystkie wyjątki od tej zasady muszą być wąsko interpretowane"26.

22 Ibidem.

23 W. Sadurski, Wolność prasy w systemie praw człowieka (wybrane zagadnienia), w: Obywatel-jego wolności i prawa. Zbiór studiów przygotowanych z okazji 10. lecia urzędu Rzecznika Praw Obywatelskich, opr. B. Oliwa-Radzikowska, Warszawa 1998, s. 142.

24 Ibidem.

25 M. A. Nowicki (opr.), Europejski Trybunał Praw Człowieka. Orzecznictwo, t. 2: Prawo do życia i inne prawa, Kantor Wydawniczy Zakamycze 2002, s. 943.

26 I. C. Kamiński, Swoboda wypowiedzi w orzeczeniach Europejskiego Trybunatu Praw Człowieka w Strasburgu, Kantor Wydawniczy Zakamycze 2002, s. 101. 
Stanowisko to należy niewątpliwie uznać za dowód legitymizacji koncepcji „wolnego rynku idei” w orzecznictwie ETPC dotyczącym wypowiedzi o charakterze politycznym. Trudno natomiast dostrzec przesłanki pozwalające stwierdzić, iż zasada free marketplace of ideas znajduje w decyzjach Trybunału także zastosowanie wobec wypowiedzi innego rodzaju, zwłaszcza tych odnoszących się do kwestii religii bądź moralności. W takich przypadkach ETPC uznaje z reguły prawo państw-stron Europejskiej Konwencji Praw Człowieka do ingerencji w zasadę swobody wypowiedzi. Znalazło to swój wyraz już w sprawie Handyside przeciw Wielkiej Brytanii, rozpatrywanej w roku 1976.

Opinia przedstawiona przez Trybunał przy okazji tego rozstrzygnięcia może uchodzić do dziś za szczególnie reprezentatywną ilustrację standardów swobody wypowiedzi obowiązujących w systemie Rady Europy. Sprowadzają się one do przekonania, że swoboda ta jest jednym z filarów społeczeństwa demokratycznego, a zarazem „warunkiem jego rozwoju i możliwości samorealizacji jednostki"27. W związku z tym, analizując okoliczności sprawy Handyside przeciw Wielkiej Brytanii, Trybunał dodał: „Nie może ona [swoboda wypowiedzi - przyp. aut.] ograniczać się do informacji i poglądów, które są odbierane przychylnie albo postrzegane jako nieszkodliwe lub obojętne, lecz odnosi się w równym stopniu do takich, które obrażają, oburzają lub wprowadzają niepokój. Takie są wymagania pluralizmu i tolerancji, bez których demokracja nie istnieje"28.

Warto jeszcze raz podkreślić, że sformułowaną wyżej zasadę, korespondującą wyraźnie ze stanowiskiem Sądu Najwyższego USA w sprawie „New York Times” przeciw Sullivanowi oraz opiniami Trybunału w Strasbourgu wyrażonymi w przywołanych wyżej sprawach: Lingens przeciw Austrii, Oberschlick przeciw Austrii oraz Castells przeciw Hiszpanii, odnosi się przede wszystkim do wypowiedzi o charakterze politycznym. Natomiast w stosunku do wypowiedzi, w których w grę wchodzą kwestie moralności i religii, Trybunał ten jest skłonny aprobować sygnalizowaną wyżej możliwość ingerencji przez państwo w prawo jego mieszkańców do wolności słowa. W sprawie Handyside przeciw Wielkiej Brytanii stanowisko to znalazło następujące uzasadnienie: „Na podstawie prawa wewnętrznego różnych państw Konwencji nie sposób znaleźć jednolitej europejskiej koncepcji moralności. Poglądy prawne w tej dziedzinie

27 M. A. Nowicki, op. cit., s. 965.

28 Ibidem. 
różnią się w zależności od czasu i miejsca, szczególnie dzisiaj, w dobie charakteryzującej się szybkimi zmianami opinii o moralności"29.

Jak warto dodać, to właśnie pogląd Trybunału dotyczący braku ,jednolitej europejskiej koncepcji moralności" wywarł zasadniczy wpływ na decyzję tego organu w omawianej tu sprawie. Stwierdzono w niej, że Anglia nie naruszyła prawa do wolności słowa, zapisanego w artykule 10 Europejskiej Konwencji Praw Człowieka, karząc grzywną Richarda Handyside’a, wydawcę książki zatytułowanej Mały czerwony podręcznik, a także orzekając konfiskatę i zniszczenie egzemplarzy tej książki zajętych wcześniej przez policję. Na takie akurat rozstrzygnięcie Trybunału wpłynął charakter wymienionej publikacji, będącej informatorem dla młodzieży od lat dwunastu, zawierającym treści, które z punktu widzenia moralności mogły oburzać mieszkańców zainteresowanej społeczności ${ }^{30}$.

Co istotne, sędziowie orzekający w tej sprawie nie uznali argumentu, że Mały czerwony podręcznik był wcześniej kolportowany w innych krajach, co nie spotkało się z takim potępieniem jak w Anglii. W ten sposób cytowana wyżej opinia Trybunału na temat „braku jednolitej europejskiej koncepcji moralności" znalazła odzwierciedlenie w rozstrzygnięciu prawnym uchodzącym za jedną z najważniejszych decyzji sądu w Strasburgu podjętych w kwestiach swobody wypowiedzi. Stanowisko to Trybunał potwierdził później m.in. w takich sprawach, jak Müller przeciw Szwajcarii z 1988 r. czy też Otto-Preminger-Institut przeciw Austrii z 1994 r. $^{31}$

29 Ibidem, s. 962.

30 W Małym czerwonym podręczniku znalazł się m.in. rozdział zatytułowany „Seks”, zawierający informacje na temat masturbacji, orgazmu, środków antykoncepcyjnych, menstruacji, pornografii, impotencji, chorób wenerycznych, aborcji - oraz adresy, pod którymi można było otrzymać pomoc i poradę w sprawach związanych z seksem.

31 Pierwsza z wymienionych spraw dotyczyła ukarania organizatorów wystawy obrazów we Friburgu oraz jednego z malarzy, którzy na tej wystawie prezentowali swoje dzieła: Józefa Felixa Müllera. Przyczyną wspomnianej kary był zarzut „obsceniczności” obrazów tego artysty, przedstawiających „w wulgarny sposób stosunki seksualne, zwłaszcza między mężczyznami i zwierzętami” (patrz: ibidem, s. 998). Trybunał, dopuszczając możliwość ingerencji państwa w prawo mieszkańców do swobody wypowiedzi, przewidziane w ust. 2 artykułu 10 Europejskiej Konwencji Praw Człowieka, orzekł, że w tym przypadku nie nastąpiło naruszenie wspomnianego artykułu. Podobna decyzja zapadła w sprawie Otto-Preminger-Institut przeciw Austrii. Chodziło w niej o emisję w Innsbrucku filmu przedstawiającego Boga Ojca jako istotę starą i schorowana, „Jezusa jako maminsynka o słabej inteligencji, a Dziewicę Maryję jako rozpustnicę bez żadnych zasad" (patrz: ibidem, s. 1057). Biorąc pod uwa- 
Tak więc w orzecznictwie Europejskiego Trybunału Praw Człowieka koncepcja „wolnego rynku idei” znajduje zastosowanie głównie w stosunku do wypowiedzi politycznych. Wobec wypowiedzi o innym charakterze - na przykład komercyjnych, zwłaszcza zaś tych odnoszących się do religii i moralności - ETPC wykazuje wyraźną powściagliwość w swej gotowości do pełnej legitymizacji doktryny free marketplace of ideas, pozostawiając w tym zakresie państwom-stronom Europejskiej Konwencji Praw Człowieka duży margines swobody ocen. Inaczej mówiąc, w kwestiach dotyczących wolności wypowiadania się (nie tylko słowem, ale także na przykład za pomocą obrazu) na temat moralności i religii - jurysdykcji ETPC nie sposób uznać za pełne urzeczywistnienie Miltonowskiej propozycji „wolnego rynku idei”, lecz co najwyżej za odbicie koncepcji „wolnego rynku idei” ograniczonego zasadą społecznej odpowiedzialności ${ }^{32}$.

Podobną opinię można wyrazić również na temat innych międzynarodowych uregulowań prawnych dotyczących kwestii swobody wypowiedzi. Na przykład artykuł 19 Międzynarodowego Paktu Praw Obywatelskich i Politycznych (MPPOiP) ONZ zawiera, analogicznie jak artykuł 10 Europejskiej Konwencji Praw Człowieka Rady Europy, ustęp ograniczający zasadę wolnego obiegu informacji i opinii. Zgodnie z paragrafem 3 MPPOiP korzystanie z prawa do swobody wypowiedzi pociaga za sobą „specjalne obowiązki i odpowiedzialność” - i podlega restrykcjom niezbędnym w celu ,poszanowania praw i dobrego imienia innych” oraz „ochrony bezpieczeństwa państwowego lub porządku publicznego albo zdrowia lub moralności publicznej"33.

Podkreślając to, warto dodać, że w przypadku paragrafu 2 artykułu 10 EKPC lista przesłanek przewidujących możliwości wprowadzenia podob-

gę fakt, że katolicyzm jest religią znacznej części społeczności, w której wspomniany film miał być pokazywany, Trybunał w Strasbourgu uznał, iż konfiskując taśmę z zapisem obrazu - władze Austrii nie naruszyły art. 10 Europejskiej Konwencji, chciały one bowiem zapewnić spokój społeczny w Tyrolu „i zapobiec poczuciu zagrożenia niedopuszczalnymi atakami na wiarę jego mieszkańców” (ibidem, s. 1062).

32 Na znaczenie słów „obowiązki i odpowiedzialność” przy korzystaniu z prawa do wolności słowa Trybunał zwrócił uwagę m.in. w związku z przywołaną wyżej sprawą Otto-Preminger-Institut przeciw Austrii. Podkreślono wówczas, że w „,ferze opinii i przekonań religijnych” należy unikać „w miarę możliwości wyrażeń, które niepotrzebnie obrażają innych, naruszając ich prawa" (ibidem, s. 1060).

33 Patrz: A. Michalska, Komitet Praw Człowieka. Kompetencje, funkcjonowanie, orzecznictwo, Helsińska Fundacja Praw Człowieka, Warszawa 1994, s. 187. 
nych ograniczeń jest dłuższa. Poza wymienionymi wyżej - mówi się tu także o ,integralności terytorialnej”, „konieczności zapobieżenia zakłóceniu porządku lub przestępstwu”, ,zapobieżeniu ujawnieniu informacji poufnych”, „zagwarantowaniu powagi i bezstronności władzy sądowej”34. $\mathrm{Z}$ kolei w przypadku MPPOiP czynnikiem dodatkowo ograniczającym zasadę free marketplace of ideas jest artykuł 20, głoszący, że „wszelka propaganda wojenna powinna być ustawowo zakazana”, podobnie jak „nawoływanie do nienawiści narodowej, rasowej lub religijnej, zachęcające do dyskryminacji, wrogości lub gwałtu”35.

Mówiąc o koncepcji „wolnego rynku idei” w kontekście współczesnych standardów swobody wypowiedzi, trudno nie zauważyć, że Pierwsza Poprawka do Konstytucji USA daje tej koncepcji znacznie bardziej jednoznaczną legitymizację niż wymienione wyżej zapisy Europejskiej Konwencji Praw Człowieka i Międzynarodowego Paktu Praw Obywatelskich i Politycznych. Zdaje się to podkreślać już sama lakoniczność jej sformułowania odnoszącego się do swobody wypowiedzi (,Żadna ustawa Kongresu nie może [...] ograniczyć wolności słowa lub prasy..."36). To właśnie owa lakoniczność i pozorna jednoznaczność Pierwszej Poprawki stały się przyczynami, dla których wśród interpretatorów jej znaczenia znaleźli się zwolennicy stanowiska „absolutystycznego”, to znaczy zakładającego, że wyraz, „żadna” należy w tym zapisie pojmować dosłownie.

Zwraca na to uwagę m.in. Robert J. Wagman, zaliczający do ,absolutystów” takich sędziów Sądu Najwyższego USA, jak Hugo Black i William O. Douglas, oraz nauczyciela akademickiego Alexandra Meiklejohna ${ }^{37}$. Ten sam autor podkreśla jednak, że nawet ci zdecydowani orędownicy zasady free marketplace of ideas nie uważali, aby wolny rynek informacji i opinii mógł być rynkiem absolutnie wolnym ${ }^{38}$. Wynika to między innymi z tego, że już samo praktykowanie prawa do swobody wypowiedzi narzu-

34 M. A. Nowicki, op. cit., s. 940.

35 A. Michalska, op. cit., s. 158.

36 Patrz: K. Motyka (opr.), Prawa człowieka, Wydawnictwo „Morpol”, Lublin 1999, s. 67. Warto podkreślić, że w Pierwszej Poprawce do Konstytucji USA mówi się nie tylko o wolności słowa, lecz także o wolności sumienia i pokojowych zgromadzeń. Jej pełny zapis brzmi: „Żadna ustawa Kongresu nie może wprowadzić religii ani zabronić swobodnego praktykowania jej, ograniczyć wolności słowa lub prasy ani prawa ludu do spokojnych zgromadzeń lub do składania naczelnym władzom petycji o naprawienie krzywd" (patrz: ibidem).

37 R. J. Wagman, The First Amendment Book, Pharos Books, New York 1991, s. 85.

38 Ibidem, s. 85-86. 
ca pewne formalne ograniczenia. Stanowisko to przedstawił w szczególnie interesujący sposób wymieniony wyżej Aleksander Meiklejohn w swoim wystąpieniu przed amerykańską komisją senacką w roku 1955. Powiedział on wtedy między innymi:

„Wy i ja mówimy tutaj o wolności w ramach ograniczeń wyznaczonych przez Senat. Ja mogę mówić tylko dlatego, że wy poprosiliście mnie o to ... więcej, przydzieliliście mi temat. Zgodnie z waszym wspaniałomyślnie przygotowanym harmonogramem wypowiadane przeze mnie uwagi muszą się zamknąć w określonym przedziale czasu. Jednym słowem, moje wystąpienie, choć wolne z punktu widzenia Pierwszej Poprawki, jest ograniczone na wiele sposobów... Interpretowanie Pierwszej Poprawki jako zapisu zabraniającego wprowadzania takich ograniczeń byłoby dowodem niewłaściwego pojmowania jej znaczenia, równoznacznym z doprowadzeniem tego znaczenia do absurdu"39.

Koncepcja free marketplace of ideas, choć pozostaje do dziś najbardziej znaczącą formą konkretyzacji idei swobody wypowiedzi, jest od wielu lat krytykowana. Część specjalistów uważa ją raczej za mit niż za teorię mogącą znaleźć urzeczywistnienie w realiach codziennego życia. Należy do nich na przykład amerykański prawnik Jerome Barron, który jak zaznacza Doris A. Graber w swojej książce Mass Media and American Politics - zarzuca zwolennikom zasady „wolnego rynku idei”, że nie biorą oni pod uwagę kwestii nierównego dostępu do tego rynku przez różnych użytkowników informacji ${ }^{40}$. Na kwestię tę zwraca także uwagę Tomasz Płonkowski, podkreślający, iż zdaniem Barrona „dominująca interpretacja Pierwszej Poprawki (tj. wyłożona przez sędziów Sądu Najwyższego i uznawana przez większość sądów w Stanach Zjednoczonych) gwarantuje prawdziwą wolność jedynie właścicielom środków masowego przekazu”, dlatego „trzeba w taki sposób zmienić wykładnię Pierwszej Poprawki, by zapewniała dostęp do mediów także opiniom mniejszości”41.

39 Ibidem, s. 86.

40 Patrz: D. A. Graber, Mass Media and American Politics, Congressional Quaterly Inc., Washington DC 1989, s. 112-113. Autorka ta powołuje się na publikację J. Barrona, Freedom of the Press for Whom? The Right of Access to the Mass Media. Jak pisze Graber, Barron ,oskarża media o to, że walczą one o szeroko zakreślone prawo do swobody wypowiedzi dla siebie, odmawiając tego samego prawa społeczeństwu" (patrz: ibidem).

41 T. Płonkowski, Amerykańska koncepcja społecznej odpowiedzialności dziennikarzy, Instytut Kultury, Warszawa 1995, s. 66. 
Na pełen dystansu stosunek J. Barrona do koncepcji ,,wolnego rynku idei” wskazują również inni autorzy. Jak zaznaczają, według jego opinii koncepcja ta opiera się na fałszywych przesłankach. Jedną z nich jest przekonanie, że prawda jest czymś obiektywnie istniejącym i możliwym do odkrycia, nie zaś pojęciem subiektywnym, kreowanym bądź wybieranym; inną - założenie, iż prawda znajduje się zawsze wśród idei pojawiających się na wolnym rynku i że zawsze może ona tam przetrwać; jeszcze inną - wiara, iż ludzie są w zasadzie istotami racjonalnymi i zdolnymi do odkrywania prawdy ${ }^{42}$.

Autorem odnoszącym się krytycznie do omawianej tu koncepcji jest także Eric Barendt. Podobnie jak Barron, zwraca on uwagę na to, że nie wszyscy mająjednakowy dostęp do teoretycznie wolnego rynku informacji i opinii ${ }^{43}$. Oceniając sceptycznie zdolność ludzi do przekazywania idei zawsze „w racjonalny i inteligentny sposób”, Barendt dodaje, iż poddawać w wątpliwość można także wiarę obrońców marketplace of ideas w to, że wszyscy zabierający głos na forum publicznym wyrażają tam rzeczywiście „swoje własne poglądy lub przekazują informacje, co do których nie mają wątpliwości, że są one dokładne i mogą się przyczynić do rozwiązania jakiegoś problemu"44.

Powyższych argumentów nie sposób ignorować, choć w dobie Internetu niektóre z nich tracą przynajmniej częściowo swą aktualność. Dotyczy to przede wszystkim tezy o nierównym dostępie do rynku informacji i opinii. Będąc ,międzynarodową siecią sieci komputerowych [...] stworzoną w celu wymiany informacji" ${ }^{45}$, Internet okazuje się niewątpliwie najbardziej demokratycznym środkiem masowego przekazu, jaki do tej pory stworzono. Dzięki swemu dynamicznemu rozwojowi w ostatnich latach zapewnia on uczestnictwo w wymianie idei coraz większej rzeszy mieszkańców świata - globalnej wioski. Co istotne, Internet zdołał wyprowadzić w pole cenzorów, najwyraźniej odsyłając do lamusa długowieczną tradycję kontrolowania treści wszystkich publikacji, jeszcze zanim mogły one ujrzeć światło dzienne. Stanowi to dziś najlepsze potwierdzenie prze-

42 Patrz: First Amendment Theorists, http://www.cas.okstate.edu/jb/faculty/senat/jb3163/theorists.html, s. 2, odczyt: 24.01.2002.

43 E. Barendt, The First Amendment and the Media, w: I. Loveland (ed.), Importing the First Amendment. Freedom of Expression in American, English and European Law, Hart Publishing, Oxford 1998, s. 43.

44 Ibidem.

45 A. J. Kennedy, Internet, Wydawnictwo Pascal, Bielsko-Biała 2000, s. 16. 
konania Miltona, wyrażonego ponad 360 lat temu, że próby ograniczania niektórym autorom dostępu do rynku informacji i opinii okazują się na dłuższą metę nieskuteczne.

Dzięki Internetowi koncepcja „wolnego rynku idei” ma się dziś lepiej niż kiedykolwiek przedtem. Wprawdzie i obecnie trudno jednoznacznie rozstrzygnąć, czy Miltonowska zasada self-righting process jest teorią znajdującą odzwierciedlenie w życiu, czy też tylko „mitem retorycznym”, jednak nie ulega wątpliwości, iż przekonanie o prawdzie zdolnej zatriumfować nad fałszem w warunkach swobodnej wymiany informacji i opinii - pozostaje poglądem intrygującym domagającym się przy tym ciagłej weryfikacji. Jak się wydaje, to właśnie Internet pozostanie w przyszłości jednym z jej głównych instrumentów.

\section{Summary}

Owing to the Internet the concept of a 'free marketplace of ideas' is thriving. Although even today it is difficult to decide unanimously whether the Miltonian principle of the self-righting process is a theory reflected in real life, or rather a 'rhetoric myth', it is beyond any doubt that the conviction that under the conditions of free exchange of information and opinion truth is able to triumph over falsehood still intrigues people, who feel compelled to verify this conviction over and over again. How much the ideas referred to at the beginning of this text, namely the free marketplace of ideas and self-righting process, have taken possession of the imagination of a contemporary information recipient is demonstrated by the fact that they are echoed both in the academic studies devoted to the issue of freedom of speech and in introductory, journalistic or educational publications. It seems that in the future it will be the Internet that remains one of the main instruments to verify the rightness of the self-righting process. One should not doubt that it will be a never-ending process, as predicted by Milton. One can assume though that the concept of a 'free marketplace of ideas' will continue to exert a significant impact on the development of international standards of free speech both in Western culture and elsewhere. 